\title{
Apis andreniformis associated Actinomycetes show antimicrobial activity against black rot pathogen (Xanthomonas campestris pv. campestris)
}

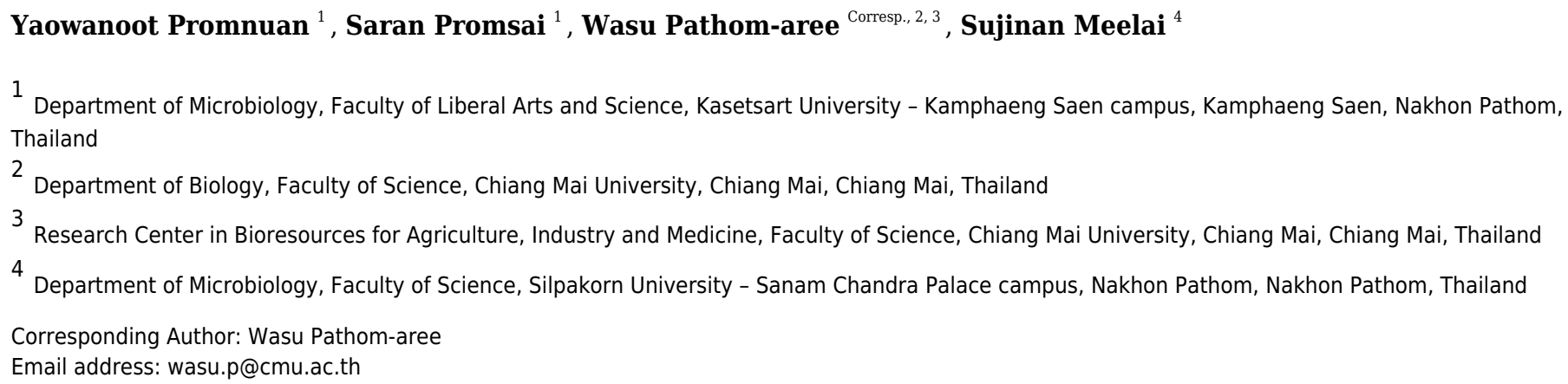

This study aimed to investigate cultivable actinomycetes associated with rare honey bee species in Thailand and their antagonistic activity against plant pathogenic bacteria. Actinomycetes were selectively isolated from the black dwarf honey bee (Apis andreniformis). A total of 64 actinomycete isolates were obtained with Streptomyces as the predominant genus (84.4\%) followed by Micromonospora (7.8\%), Nonomuraea $(4.7 \%)$ and Actinomadura (3.1\%). All isolates were screened for antimicrobial activity against Xanthomonas campestris pv. campestris, Pectobacterium carotovorum and Pseudomonas syringae $\mathrm{pv}$. sesame. Three isolates inhibited the growth of $X$. campestris $\mathrm{pv}$. campestris during in vitro screening. The crude extracts of two isolates (ASC3-2 and ASC5-7P) had a minimum inhibitory concentration (MIC) of $128 \mathrm{mg} \mathrm{L}^{-1}$ against $X$. campestris pv. campestris. For isolate ACZ2-27, its crude extract showed stronger inhibitory effect with a lower MIC value of $64 \mathrm{mg} \mathrm{L}^{-1}$ against $X$. campestris pv. campestris. These three active isolates were identified as members of the genus Streptomyces based on their 16S rRNA gene sequences. Phylogenetic analysis based on the maximum likelihood algorithm showed that isolate ACZ2-27, ASC3-2 and ASC5-7P were closely related to Streptomyces misionensis NBRC $13063^{\top}$ (99.71\%), Streptomyces cacaoi subsp. cacaoi NBRC $12748^{\top}(100 \%)$ and Streptomyces puniceus NBRC $12811^{\top}$ (100\%), respectively. In addition, representative isolates from non-Streptomyces groups were identified by 16S rRNA gene sequence analysis. High similarities were found with members of the genera Actinomadura, Micromonospora and Nonomuraea. Our study provides evidence of actinomycetes associated with the black dwarf honey bee including members of rare genera. 
Antimicrobial potential of these insect associated Streptomyces was also demonstrated especially the antibacterial activity against phytopathogenic bacteria. 
1 Apis andreniformis Associated Actinomycetes Show Antimicrobial Activity

2 Against Black Rot Pathogen (Xanthomonas campestris pv. campestris)

3

4

5

6

7

8

9

10

11

12

13

14

15

16

17

18

19

20

21

22

23

24

25

26

27

28

29

30

31

32

33

34

35

36

37

38

39

40

Yaowanoot Promnuan ${ }^{1}$, Saran Promsai ${ }^{1}$, Wasu Pathom-aree ${ }^{2,3}$ and Sujinan Meelai ${ }^{4}$

${ }^{1}$ Department of Microbiology, Faculty of Liberal Arts and Science, Kasetsart University Kamphaeng Saen campus, Nakhon Pathom 73140, Thailand.

${ }^{2}$ Department of Biology, Faculty of Science, Chiang Mai University, Chiang Mai 50200, Thailand.

${ }^{3}$ Research Center in Bioresources for Agriculture, Industry and Medicine, Faculty of Science, Chiang Mai University, Chiang Mai 50200, Thailand

${ }^{4}$ Department of Microbiology, Faculty of Science, Silpakorn University - Sanam Chandra Palace campus, Nakhon Pathom 73000, Thailand.

Corresponding Author:

Wasu Pathom-aree ${ }^{2,3}$

${ }^{2}$ Department of Biology, Faculty of Science, Chiang Mai University, Chiang Mai 50200, Thailand.

${ }^{3}$ Research Center in Bioresources for Agriculture, Industry and Medicine, Faculty of Science, Chiang Mai University, Chiang Mai 50200, Thailand

Email address: wasu.p@cmu.ac.th; Tel.: +66 53 943346-48

\section{Abstract}

This study aimed to investigate cultivable actinomycetes associated with rare honey bee species in Thailand and their antagonistic activity against plant pathogenic bacteria.

Actinomycetes were selectively isolated from the black dwarf honey bee (Apis andreniformis). A total of 64 actinomycete isolates were obtained with Streptomyces as the predominant genus (84.4\%) followed by Micromonospora (7.8\%), Nonomuraea (4.7\%) and Actinomadura (3.1\%). All isolates were screened for antimicrobial activity against Xanthomonas campestris pv. campestris, Pectobacterium carotovorum and Pseudomonas syringae pv. sesame. Three isolates inhibited the growth of $X$. campestris pv. campestris during in vitro screening. The crude extracts of two isolates (ASC3-2 and ASC5-7P) had a minimum inhibitory concentration (MIC) of 128 $\mathrm{mg} \mathrm{L}^{-1}$ against $X$. campestris pv. campestris. For isolate ACZ2-27, its crude extract showed stronger inhibitory effect with a lower MIC value of $64 \mathrm{mg} \mathrm{L}^{-1}$ against $X$. campestris pv. campestris. These three active isolates were identified as members of the genus Streptomyces based on their 16S rRNA gene sequences. Phylogenetic analysis based on the maximum likelihood algorithm showed that isolate ACZ2-27, ASC3-2 and ASC5-7P were closely related to Streptomyces misionensis NBRC $13063^{\mathrm{T}}(99.71 \%)$, Streptomyces cacaoi subsp. cacaoi NBRC $12748^{\mathrm{T}}(100 \%)$ and Streptomyces puniceus NBRC $12811^{\mathrm{T}}(100 \%)$, respectively. In addition, representative isolates from non-Streptomyces groups were identified by 16S rRNA gene sequence analysis. High similarities were found with members of the genera Actinomadura, Micromonospora and Nonomuraea. Our study provides evidence of actinomycetes associated with the black dwarf honey bee including members of rare genera. Antimicrobial potential of

Peer) reviewing PDF | (2021:02:57892:2:0:NEW 10 Jul 2021) 
41 these insect associated Streptomyces was also demonstrated especially the antibacterial activity

42 against phytopathogenic bacteria.

43 Keywords: Honey bee; Apis andreniformis; Insect associated actinomycetes; Streptomyces; Rare

44 actinomycetes; Plant pathogenic bacteria; Xanthomonas campestris pv. campestris

45

46

47

48

49

50

51

52

53

54

55

56

57

58

59

60

61

62

63

64

65

66

67

68

69

70

71

72

73

74

75

76

77

78

79

80

\section{Introduction}

Apis andreniformis or black dwarf honey bee is one of the rare native bees found in Thailand and both tropical and near subtropical regions of Southeast Asia (Hepburn \& Radloff, 2011). They build a single, exposed comb on the small branches of shrubs, banana, bamboos or small trees (Wongsiri et al., 1996). Actinomycetes are Gram-positive bacteria which produce two types of branching mycelia, namely aerial and substrate mycelium. They are well known as prolific producer of bioactive compounds, especially members of the Streptomyces species. Actinomycetes are widely distributed in nature both in terrestrial and aquatic environments (Goodfellow \& Williams, 1983). They are recently found to be associated with several insects such as ants (Currie et al., 1999; Currie et al.,2003; Cafaro \& Currie, 2005; Oh et al., 2009; Van Arnama et al., 2016; Chevrette et al., 2019), leafcutter bees (Inglis et al., 1993), wasp (Kroiss et al., 2010; Matarrita-Carranza et al., 2021), southern pine beetle (Scott et al., 2008), honey bees and stingless bees (Promnuan et al., 2009; Promnuan et al., 2011; Promnuan et al., 2020).

There are few studies on actinomycetes associated with honey bee (Apis) species in Thailand. Actinomycetes belonging to the genera Streptomyces, Nonomurea and Nocardiopsis were isolated from three species of honey bees (Apis mellifera, Apis cereana and Apis florea) collected from northern Thailand. Furthermore, some of these isolates were able to inhibit the growth of Paenibacillus larvae and Melisococcus plutonius in vitro (Promnuan et al., 2009). A novel actinobacterial species, Actinomadura apis was isolated from an A. mellifera hive in Chiang Mai province, Thailand (Promnuan et al., 2011). In addition, Streptomyces spp. isolated from giant honey bee (Apis dorsata) showed the ability to inhibit the growth of Xanthomonas oryzae pv. oryzae, Xanthomonas campestris pv. campestris, Ralstonia solanacearum and Pectobacterium carotovorum (Promnuan et al., 2020). These studies indicated that honey bees harbored actinomycetes with potential to produce novel antimicrobial compounds to combat bacterial diseases in agriculture. Nevertheless, currently the discovery rate of new antibiotics from actinomycetes has been declining especially those from common habitats. Therefore, the focus of search and discovery programs for novel antibiotics from actinomycetes has shifted toward unexplored habitats (Bundale et al., 2015; Rangseekaew \& Pathom-aree, 2019). In addition, rare actinomycetes are of interest for drug discovery programs as they are producers of many antibiotics in the market including rifamycins (Amycolatopsis mediterranei) and erythromycin (Saccharopolyspora erythraea). During the last two decades, known antibiotics produced by rare actinomycetes are increased up to 25-30\% (Ding et al. 2019). The Gramnegative bacterium, $X$. campestris pv. campestris, is known to cause significant losses in many crop plants from diseases such as tomato speck, rice and pomegranate bacterial blight, citrus canker and brassica black rot (Yan et al., 2019). This bacterium can cause disease in a large 
81 number of species in the Brassicaceae, including Brassica and Arabidopsis. Black rot is a seed-
82 borne disease and typical symptoms include V-shaped yellow lesions starting from the leaf

82

83

84

85

86

87

88

89

90

91

92

93

94

95

96

97

98

99

100

101

102

103

104

105

106

107

108

109

110

111

112

113

114

115

116

117

118

119

120 margins and blackening of the veins (Vicente and Holub, 2013). The use of bactericidal compounds to control phytopathogenic bacteria such as antibiotics and copper could cause serious problems to human health and environment such as antibiotic resistance and toxicity. Furthermore, some emerging strains have shown strong resistance to the antibiotics (Satish et al., 2002; Sabir et al., 2017; Mougou \& Boughalleb-M'hamdi, 2018; Wu et al., 2019). For these reasons, other control measures have been developed and reported including antagonistic bacteria (Bacillus spp. and Pseudomonas spp.) (Wulff et al., 2002; Mishra \& Arora, 2012), antimicrobial compounds from plant extracts (Satish et al., 2002; Kaur et al., 2016) and essential oils (Sabir et al., 2017; Amini et al., 2018).

Actinomycetes isolated from the black dwarf honey bee (A. andreniformis) with antagonistic activity against the phytobacterial pathogen have never been studied and reported. Therefore, this study focused on the isolation of cultivable actinomycetes from $A$. andreniformis collected from Chiang Mai province, Thailand and their antimicrobial activity against phytopathogenic bacteria was investigated.

\section{Materials \& Methods}

\section{Sample collection}

This study was approved by the Institutional Animal Care and the Use Committee (IACUC), Silpakorn University (Ethic number: 8603.16/0328). A. andreniformis combs were obtained from the local villages in Mae-rim district, Chiang Mai province, Thailand during October 2013-January 2014. The permission was received from the farm owners (Mr. Ton Tatiya and Mr. Ma Madamun). Six combs were stored in sterilized containers and transferred back to the laboratory. The samples (adult bees, pupae, honey and pollen) were kept in sterile plastic tubes and stored at $-20{ }^{\circ} \mathrm{C}$ until further processing.

\section{Isolation and characterization of actinomycetes from $A$. andreniformis}

Actinomycetes were isolated from six combs of $A$. andreniformis. Five adult bees and pupae were taken from each of the six collected combs, surface sterilized and ground before the isolation process. Isolation of actinomycetes from one milliliter of honey and one gram of pollen was achieved using a standard 10-fold dilution spread plate method on glycerol-asparagine (ISP5) (Pridham \& Lyons, 1961), starch casein nitrate agar (Küster \& William, 1964), Czapek's agar (Waksman, 1950) and nutrient agar supplemented with $25 \mu \mathrm{g} \mathrm{mL}-1$ of nalidixic acid and nystatin. All plates were incubated at $30{ }^{\circ} \mathrm{C}$ for $14-21$ days. Presumptive actinomycetes colonies were purified and maintained on yeast extract-malt extract agar (ISP2) (Shirling \& Gottlieb, 1966) slants and kept in $4{ }^{\circ} \mathrm{C}$. Sixty-four actinomycetes were grouped based on their morphological characteristics in particular the colour of substrate mycelium, aerial spore mass and diffusible pigments. 
121

122

123

124

125

126

127

128

129

130

131

132

133

134

135

136

137

138

139

140

141

142

143

144

145

146

147

148

149

150

151

152

153

154

155

156

157

158

159

160

\section{Phytopathogenic bacteria}

The bacterial phytopathogens, $X$. campestris pv. campestris and $P$. carotovorum were obtained from the Department of Agriculture, Ministry of Agriculture and Cooperative, Thailand. Pseudomonas syringae pv. sesame TISTR 901 was obtained from Thailand Institute of Scientific and Technological Research (TISTR), Thailand. These phytopathogenic bacteria were activated and maintained on nutrient agar and yeast extract-malt extract (ISP2) agar for 24-48 hours, at $30^{\circ} \mathrm{C}$ before use.

\section{Screening for antagonistic activity of actinomycetes against plant pathogenic bacteria}

All actinomycete isolates were tested for their activity against three plant pathogenic bacteria (X. campestris pv. campestris, P. carotovorum and Ps. syringae pv. sesame TISTR 901) using a modified cross streak method as described by Promnuan et al. (2020) on glucose yeast extract (GYE) and ISP2 agar plate. The inhibition zones were recorded after 24 hours. Each experiment was performed in triplicate.

\section{Extraction of bioactive compounds from potent actinomycete isolates.}

Selected actinomycete isolates that showed potent activity against the growth of $X$. campestris pv. campestris from the cross-streaking method were grown on ISP2 agar plates (for ACZ2-27) and GYE agar plates (for ASC3-2 and ASC5-7P) and incubated at $30^{\circ} \mathrm{C}$. After 14 days incubation, the agar media of each isolate was extracted using ethyl acetate followed the method as described by Promnuan et al. (2020). Briefly, small pieces of agar medium (approximately $0.5 \mathrm{~cm} \times 0.5 \mathrm{~cm}$ ) were added to $200 \mathrm{ml}$ of ethyl acetate and shaken at $150 \mathrm{rpm}$, $30^{\circ} \mathrm{C}$ for $48 \mathrm{~h}$. The extracts were filtered through Whatman No. 1 filter paper and concentrated in a rotary evaporator at $40^{\circ} \mathrm{C}$. One microliter of sterile dimethyl sulfoxide (DMSO) was added into the dried extracts and stored at $-20^{\circ} \mathrm{C}$.

\section{Determination of minimum inhibitory concentration (MIC) of antagonistic actinomycete isolates}

The MIC of ethyl acetate extract was determined using modified broth microdilution method in 96-well microtiter plate as described by Wiegand et al. (2008). The concentration of the test organism, $X$. campestris pv. campestris was adjusted to $0.5 \mathrm{McFarland}$ standard. The initial concentration of the crude extract was adjusted to $1,280 \mathrm{mg} \mathrm{L}^{-1}$ using sterile DMSO. The crude extract was prepared as two-fold dilution series using ISP2 broth in a 96-well microtiter plate. The concentration of the crude extract was ranged from 0.25 to $128 \mathrm{mg} \mathrm{L}^{-1}$. Sterile DMSO was used as a negative control. After incubation at $30{ }^{\circ} \mathrm{C}$ for 24 hours, the suspension from each well was inoculated onto an ISP2 agar plate using streak plate technique. Plates were incubated at $30{ }^{\circ} \mathrm{C}$ for 24 hours. The lowest concentration of the extracts that showed no bacterial growth on the ISP2 agar plate was recorded as the MIC value. This experiment was conducted in triplicate. 
161

162

163

164

165

166

167

168

169

170

171

172

173

174

175

176

177

178

179

180

181

182

183

184

185

186

187

188

189

190

191

192

193

194

195

196

197

198

199

200

\section{Identification of actinomycetes using $16 \mathrm{~S}$ rRNA gene}

The representative isolates of each morphological group and the actinomycetes that showed strong activity against $X$. campestris pv. campestris were grown in ISP2 broth, incubated at $30^{\circ} \mathrm{C}$ for 7 days on the rotary shaker $\left(120 \mathrm{rev} \mathrm{min}^{-1}\right)$. The cells were collected by centrifugation $(91,000 \mathrm{~g})$ and washed three times using sterile distilled water. Genomic DNA extraction and PCR amplification of the 16S rRNA gene were carried out as described by Nakajima et al. (1999) using primers 20F (5'-AGTTTGATCCTGGCTC) and 1540R (5'AAGGAGGTGATCCAGCC). The PCR product was purified using Invitrogen ${ }^{\mathrm{TM}}$ PureLink ${ }^{\mathrm{TM}}$ PCR Purification Kit (Thermo Fisher Scientific, USA). The 16S rRNA genes were sequenced by 1st BASE, Singapore using the Sanger method. BLAST analysis of actinomycete isolates was done using the EzBioCloud database (https://www.ezbiocloud.net/) (Yoon et al., 2017). Multiple alignment of the closely related type strain sequences obtained from the GenBank database were carried out using Clustal_W in BioEdit Sequence Alignment Editor 7.2.5 (Hall, 1999). The maximum likelihood (ML) trees were constructed using MEGA X version 10.1.8 (Kumar et al., 2018) based on a comparison of 1,299-1,386 nucleotides present in all the strains used after elimination of gaps and ambiguous nucleotides from the sequences. Streptomyces thermocarboxydus DSM $44293^{\mathrm{T}}$ was used as an outgroup. Bootstrap analyses based on 1,000 resamplings was used to determine the confidence values for branches of the maximum likelihood (ML) tree (Felsenstein, 1985). The percentage of sequence similarity were calculated using the pairwise alignments function in BioEdit 7.2.5.

\section{Results}

\section{Isolation and characterization of the actinomycetes from $A$. andreniformis}

Adult bees, pupae, honey and pollen were obtained from six combs of the black dwarf honey bee (A. andreniformis). A total of sixty-four actinomycetes were isolated from different media as summarized in Table 1. Most actinomycetes were obtained from adult bees $(65.6 \%)$ followed by honey (20.3\%), pollen (12.5\%) and pupae (1.6\%). Based on the morphological characteristics, all actinomycete isolates were assigned to four groups (Table 2). Streptomyces (group IV) was the predominant genus with $84.4 \%$ followed by Micromonospora (group I) (7.8\%), Nonomuraea (group III) (4.7\%) and Actinomadura (group II) (3.1\%). Streptomyces (ACZ2-27 and ASC3-2) and all rare genera were recovered from the adult honey bee (Table 2).

\section{Antimicrobial activity of actinomycetes against phytobacterial pathogens}

Three isolates from group IV (ACZ2-27, ASC3-2 and ASC5-7P) showed strong inhibition of the growth of a phytobacterial pathogen. Actinomycete isolate ACZ2-27 inhibited the growth of $X$. campestris pv. campestris on an ISP2 agar plate (Figure 1a) with an inhibition zone diameter of $10.75 \pm 0.83 \mathrm{~mm}$. The actinomycete isolates ASC3-2 and ASC5-7P inhibited the growth of $X$. campestris pv. campestris on a GYE agar plate (Figure 1b,1c) with an inhibition zone diameter of $6.00 \pm 0.71$ and $9.0 \pm 0.82 \mathrm{~mm}$, respectively. The MIC levels of ethyl acetate extracts of the three isolates were determined against the growth of $X$. campestris pv. 
201

202

203

204

205

206

207

208

209

210

211

212

213

214

215

216

217

218

219

220

221

222

223

224

225

226

227

228

229

230

231

232

233

234

235

236

237

238

239

campestris using the 96-well microtiter assay. The MIC value of the crude extract of ACZ2-27 against $X$. campestris pv. campestris was $64 \mathrm{mg} \mathrm{L}^{-1}$ and the MIC values of the crude extracts of ASC3-2 and ASC5-7P were $128 \mathrm{mg} \mathrm{L}^{-1}$. These results provide the first evidence of antibacterial extracts from black dwarf honey bee associated actinomycetes against the black rot pathogen, $X$. campestris pv. campestris.

\section{Identification of actinomycetes using 16S rRNA gene}

Three actinomycete isolates which showed strong inhibition against the growth of $X$. campestris pv. campestris were identified based on the 16S rRNA gene sequence analysis. The 16S rRNA gene sequences of strains ACZ2-27 (LC500236), ASC3-2 (LC506284) and ASC5-7P (LC506285) were analyzed by BLAST in the EzBioCloud database. All strains exhibited high similarities with members of the genus Streptomyces. The 16S rRNA gene sequences of all three isolates were compared with the corresponding sequences of the most closely related strains of the genus Streptomyces. The maximum likelihood tree (Figure 2) revealed that strain ACZ2-27, ASC3-2 and ASC5-7P were closely related to S. misionensis NBRC 13063 ${ }^{\mathrm{T}}$, S. cacaoi subsp. cacaoi NBRC $12748^{\mathrm{T}}$ and $S$. puniceus NBRC $12811^{\mathrm{T}}$. The $16 \mathrm{~S}$ rRNA gene sequence similarity percentage between each isolate and their closely related type strains was calculated using the pairwise alignment option in BioEdit program version 7.2.5. The results revealed that isolates ACZ2-27, ASC3-2 and ASC5-7P were closely related to S. misionensis NBRC $13063^{\mathrm{T}}(99.71 \%)$, S. cacaoi subsp. cacaoi NBRC $12748^{\mathrm{T}}(100 \%)$ and $S$. puniceus NBRC $12811^{\mathrm{T}}(100 \%)$, respectively. This is the first report of actinomycete species isolated from the black dwarf honey bee (A. andreniformis) that showed the ability to produce antimicrobial metabolites that inhibited the growth of the phytobacterial pathogen $X$. campestris pv. campestris.

In addition, the representative isolates of group I (AGA3-9, AGA3-53), group II (AGA358 ) and group III (ASC2-5) were identified by $16 \mathrm{~S}$ rRNA gene sequence analysis. The $16 \mathrm{~S}$ rRNA gene sequences of strains AGA3-9 (LC546088), AGA3-53 (LC546089), AGA3-58 (LC546090) and ASC2-5 (LC546091) were analyzed by BLAST using the EzBioCloud database. The representative isolates from group I-III exhibited high similarity with members of the genera Micromonospora, Actinomadura and Nonomuraea, respectively (Table 2). The 16S rRNA gene sequence similarity between each representative isolate and their closely related type strains showed that group I (AGA3-9 and AGA3-53) were most closely related to Micromonospora chalcea DSM 43026 $6^{\mathrm{T}}(99.34 \%)$ and $M$. halotolerans CR18 ${ }^{\mathrm{T}}(99.70 \%)$, respectively. The representative isolates of group II (AGA3-58) and group III (ASC2-5) were closely related with Actinomadura meyerii DSM 44715 ${ }^{\mathrm{T}}$ (99.34\%) and Nonomuraea salmonea DSM $43678^{\mathrm{T}}(99.92 \%)$, respectively. The maximum likelihood tree also confirmed the placement of these actinomycetes to their respective genera (Figure 3 ). This is the first evidence of rare actinomycetes associated with the black dwarf honey bee $A$. andreniformis.

\section{Discussion}


240

241

242

243

244

245

246

247

248

249

250

251

252

253

254

255

256

257

258

259

260

261

262

263

264

265

266

267

268

269

270

271

272

273

274

275

276

277

278

279
In this study, Streptomyces were found as the majority of the obtained isolates. In addition, members of rare actinomycete genera Micromonospora, Nonomuraea and Actinomadura were recovered from the black dwarf honey bee. All of these isolates were recovered from the adult honey bee except for isolate ASC5-7P which was obtained from the pollen. Actinomycetes belonging to the genera Streptomyces, Nonomurea and Nocardiopsis have been previously isolated from three species of honey bees (A. mellifera, A. cereana and A. florea) collected from northern Thailand (Promnuan et al., 2009). Recently, Streptomyces spp. were also isolated from giant honey bee (A. dorsata) (Promnuan et al., 2020). These observations suggested that members of the genus Streptomyces may be commonly isolated from at least 5 species of honey bee in Thailand (A. mellifera, A. cereana, A. florea, A. dorsata and A. andreniformis). The evidence of rare actinomycetes associated with the black dwarf honey bee, A. andreniformis, implied that this honey bee species may harbor diverse actinomycete populations. It is also interesting to note that members of the genus Micromonospora were isolated from honey bee for the first time. Though, the function of these associated actinomycetes in A. andreniformis is still unknown, it is tempting to suggest that this relationship is at least neutral to the bees as all the bee samples used for isolation were healthy.

Actinomycetes are known for the production of bioactive compounds with antimicrobial activity against plant pathogens such as bacteria and fungi (Viaene et al., 2016). Several actinomycete species obtained from various habitats have been reported for secondary metabolites against phytopathogens. Streptomyces spp. obtained from marine samples in Egypt showed variable antimicrobial activity, secretion of numerous hydrolytic enzymes, in vitro and in vivo nematicidal activity against root-knot nematodes and supported plant growth (Rashad et al., 2015). S. violaceusniger strain A5 isolated from chitin-rich partially decomposed molted snake skin, showed strong inhibitory activity against Xanthomonas axonopodis pv. punicae, the causative agent of oily spot disease in pomegranate, with a MIC in the range of $0.625-1.25 \mathrm{mg}$ $\mathrm{mL}^{-1}$ (Chavan et al., 2016). Endophytic Streptomyces spp. (AB131-1 and AB131-2) reduced the infection of $X$. oryzae pv. oryzae a causal agent of bacterial leaf blight (BLB disease) and improved the growth of rice seedlings in a pot experiment in the greenhouse (Hastuti et al., 2012). Streptomyces isolated from compost-amended soil had antimicrobial activity against Agrobacterium tumefaciens. (Cuesta et al., 2010). S. caeruleatus isolated from the Cassia fistula rhizosphere soil showed strong activity against $X$. campestris pv. glycine, the soybean pathogen (Mingma et al., 2014). It is evident from these studies and our results that Streptomyces are effective in control of plant pathogens including Xanthomonas species.

Several publications support the view that insects provide new sources of actinomycetes that may produce novel natural products with antimicrobial properties (Chevrette et al., 2019). Streptomyces spp. have been isolated from $A$. andreniformis and showed high activity in reducing the egg hatch rate, increasing the infective second-stage juvenile mortality rate of the root-knot nematode (Meloidogyne incognita) and reducing root gall of chili in a pot experiment (Santisuk et al, 2018). This study and our results indicated that the black dwarf honey bee ( $A$. andreniformis) is an interesting new source for screening of actinomycetes that may produce

Peer] reviewing PDF | (2021:02:57892:2:0:NEW 10 Jul 2021) 
280

281

282

283

284

285

286

287

288

289

290

291

292

293

294

295

296

297

298

299

300

301

302

303

304

305

306

307

308

309

310

311

312

313

314

315

316

317

318

319

novel natural products for agriculture. Streptomyces spp., Nonomurea spp. and Nocardiopsis spp. were isolated from honey bees (A. mellifera, A. cereana and A. florea) and showed antibacterial activity against the growth of Paenibacillus larvae and Melisococcus plutonius that cause American foulbrood and European foulbrood disease in honey bee (Promnuan et al, 2009). The actinobacteria (Pseudonocardia spp.) associated with fungus-growing ants (Apterostigma dentigerum) produced dentigerumycin which inhibited the growth of parasitic fungus (Escovopsis sp.) (Oh et al, 2009). Poulsen et al. (2011) reported the novel macrocyclic lactam, sceliphrolactam compounds from Streptomyces symbionts with mud dauber wasps (Chalybion californicum and Sceliphron caementarium). Streptomyces spp., Micromonospora spp. and Actinoplanes spp. obtained from the paper wasp Polistes dominulus nests showed antibacterial activity against the growth of some pathogenic bacteria (Pseudomonas aeruginosa, Escherichia coli, Staphylococcus aureus, Serratia marcescens and Bacillus subtilis) (Madden et al. 2013). A novel compound cyphomycin was isolated from Streptomyces (ISID311) isolated from the microbiome of the fungus-growing ant which active against multidrug resistant fungal pathogens (Chevrette et al., 2019). Matarrita-Carranza et al. (2021) reported the genome sequence and the potential for antibiotic production of Streptomyces sp. M54, actinomycetes associated with the eusocial wasp (Polybia plebeja). This actinobacterium produces antimicrobial compounds that are active against Hirsutella citriformis, a natural fungal enemy of its host, and the human pathogens Staphylococcus aureus and Candida albicans. Recently, three actinomycetes ( $S$. ramulosus, $S$. axinellae and $S$. drozdowiczii) isolated from giant honey bee (A. dorsata) combs showed the ability to inhibited the growth of black rot pathogen (X. campestris pv. campestris) with MIC value $32 \mathrm{mg} \mathrm{L}^{-1}$ (Promnuan et al, 2020). These data indicated that actinomycetes associated with insects represent a valuable source for new antimicrobial compounds.

\section{Conclusions}

Black rot disease, which is caused by X.campestris pv. sampestris, can cause significant losses of the Brassicaceae in Asian countries. In this study, we provide evidence that actinomycetes including members of rare genera are associated with the black dwarf honey bee (A. andreniformis) especially in adult stage. The organic extract of isolate ACZ2-27 showed the lowest MIC of $64 \mathrm{mg} \mathrm{L}^{-1}$ against the growth of black rot pathogen (X. campestris pv.

campestris). This isolate was obtained from an adult bee and is phylogenetically closely related to $S$. misionensis. This is the first report of actinomycetes isolated from black dwarf honey bee which showed growth inhibitory activity against phytopathogenic bacterium pathogen, $X$. campestris pv. campestris. Black dwarf honey bee associated actinomycetes may represent an interesting source for the search of bioactive compounds for biotechnological usage, especially in agriculture.

\section{Acknowledgements}

This study was supported by the Department of Microbiology, Faculty of Liberal Arts and Science, Kasetsart University (Kamphaeng Saen campus) of the year 2018, the Research 
320 Promotion and Technology Transfer Center (RPTTC) of the Faculty of Liberal Arts and Science, 321 Kasetsart University (Kamphaeng Sean campus), Grant SRIF-JRG-2562-04 from the Faculty of

322 Science, Silpakorn University, Nakhon Pathom and partially supported by Chiang Mai

323 University. There was no additional external funding received for this study.

324

325

326

327

328

329

330

331

332

333

334

335

336

337

338

339

340

341

\section{References}

Amini, L.; Soudi, M.R.; Saboora, A.; Mobasheri, H. 2018. Effect of essential oil from Zataria multiflora on local strains of Xanthomonas campestris: An efficient antimicrobial agent for decontamination of seeds of Brassica oleracea var. capitata. Scientia Horticulturae 236: 256264.

Bundale, S.; Singh, J.; Begde, D.; Nashikkar, N.; Upadhyay, A. 2019. Rare actinobacteria: a potential source of bioactive polyketides and peptides. World Journal of Microbiology and Biotechnology 35: 92.

Cafaro, M; Currie, C. 2005. Phylogenetic analysis of mutualistic filamentous bacteria associated with fungus-growing ants. Canadian Journal of Microbiology51:441-446.

Chavan, N.P.; Pandey, R.; Nawani, N.; Nanda, R.K.; Tandon, G.D.; Khetmalas, M.B. 2016. Biocontrol Potential of Actinomycetes against Xanthomonas axonopodis pv. punicae, A Causative Agent for Oily Spot Disease of Pomegranate. Biocontrol Science and Technology. 26 (3): 351-372.

Chevrette, M.G.; Carlson, C.M; Ortega, H.E.; Thomas, C.; Ananiev, G.E.; Barn, K.J.; Book, A.J.; Cagnazzo, J.; Carlos, C.; Flanigan, W.; Grubbs, K.J.; Horn, H.A.; Hoffmann, F.M.;

342

343

344

345

346

347

348

349

350

351

352

353

354

355

356

357

358

Klassen, J.L.; Knack, J.L.; Lewin, G.R.; McDonald, B.R.; Muller, L.; Melo, W.G.P.; Pinto-

Thomas, A.A.; Schmitz, A.; Wendt-Pienkowski, E.; Widman, S.; Zhao, M.; Zhang, F.; Bugni, T.S.; Andes, D.R.; Pupo, M.T; Currie, C.R. 2019. The antimicrobial potential of Streptomyces from insect microbiomes. Nature Communications.10:516.

Cuesta, G.; García-de-la-Fuente, R.; Abad, M.; Fornes, F. 2010. Isolation and identification of actinomycetes from a compost-amended soil with potential as biocontrol agents. Journal of Environmental Management 95:280-284.

Currie, C.R.; Scott, J.A.; Summerbell, R.C.; Malloch, D. 1999. Fungus-growing ants use antibiotic-producing bacteria to control garden parasites. Nature 398:701-704.

Currie, C.R.; Wong, B.; Stuart, A.E.; Schultz, T.R.; Rehner, S.A.; Mueller, U.G.; Sung, G.H.; Spatafola, J.W.; Starus, N.A. 2003. Ancient tripartite coevolution in the attine ant-microbe symbiosis. Science 299:386-388.

Ding, T.; Yang, L.-J.; Zhang, W.-D.; Shen, Y.-H. 2019. The secondary metabolites of rare actinomycetes: chemistry and bioactivity. RSC Advances 9: 21964.

Felsenstein, J. 1985. Confidence limits on phylogenies: an approach using the bootstrap. Evolution 39:783-791.

Goodfellow, M.; Williams, S.T. 1983. Ecology of actinomycetes. Annual review of microbiology $37: 189-216$.

Peerj reviewing PDF | (2021:02:57892:2:0:NEW 10 Jul 2021) 
359

360

361

362

363

364

365

366

367

368

369

370

371

372

373

374

375

376

377

378

379

380

381

382

383

384

385

386

387

388

389

390

391

392

393

394

395

396

397

Hall, T.A.1999. BioEdit: a user-friendly biological sequence alignment editor and analysis program for Windows 95/98/NT. Nucleic Acids Symposium Series 41:95-98.

Hepburn, H.R; Radloff, S.E. 2011. Biogeography of the dwarf honeybees, Apis andreniformis and Apis florea. Apidologie 42(3):293-300.

Hastuti, R.D.; Lestari, Y.; Suwanto, A.; Saraswati, R. 2012. Endophytic Streptomyces spp. as biocontrol agents of rice bacterial leaf blight pathogen (Xanthomonas oryzae pv. oryzae). Hayati 19(4):155-162.

Inglis, G.D.; Sinler, L; Goette, M.S. 1993. Aerobic microorganisms associated with alfalfa leafcutter bees megachile rotundata. Microbial ecology 26:125-143.

Ishikawa, R.; Suzuki-Nishimito, M.; Fukuchi, A.; Matsuura, K. 2004. Effective control of cabbage black rot by Validamycin A and its effect on extracellular polysaccharide-production of Xanthomonas campestris pv. campestris. Journal of Pesticide Science 29(3):209-213.

Kaur, H.; Nyochembeng, L.N.; Mentreddy, S.R.; Banerjee, P.; Cebert, E. 2016. Assessment of

the antimicrobial activity of Lentinula edodes against Xanthomonas campestris pv. vesicatoria. Crop Protection 89:284-288.

Kroiss, J.; Kaltenpoth, M.; Schneider, B.; Schwinger, M.G.; Hertweck, C.; Maddula, R.K., Strohm, E.; A. Svatos. 2010. Symbiotic streptomycetes provide antibiotic combination prophylaxis for wasp offspring. Nature Chemical Biology 6:261-263.

Kumar, S.; Stecher, G.; Li, M.; Knyaz, C.; Tamura, K. 2018. MEGA X: molecular evolutionary genetics analysis across computing platforms. Molecular Biology and Evolution 35:1547-1549

Küster, E., Williams, S.T. 1964. Selection of media for isolation of streptomycetes. Nature 202: 928-929.

Madden, A.A.; Grassetti, A.; Soriano, J.N.; Starks P.T. 2013. Actinomycetes with antimicrobial activity isolated from paper wasp (Hymenoptera: Vespidae: Polistinae) Nests. Environmental Entomology 42(4): 703-710.

Matarrita-Carranza, B.; Murillo-Cruz, C.; Avendano, R.; Isabel Rios, M.; Chavarria, M.; GomezCalvo, M.L.; Tamayo-Castillo, G.; Araya,J.J.; Pinto-Tomas, A.A. 2021. Streptomyces sp. M54: an actinobacteria associated with a neotropical social wasp with high potential for antibiotic production. Antonie van Leeuwenhoek 114:379-398.

Mingma, R.; Pathom-aree, W.; Trakulnaleamsai, S.; Thamchaipenet, A; Duangmal, K. 2014. Isolation of rhizospheric and roots endophytic actinomycetes from Leguminosae plant and their activities to inhibit soybean pathogen, Xanthomonas campestris pv. glycine. World Journal of Microbiology and Biotechnology 30:271-280.

Mishra, S; Arora, N.K. 2012. Evaluation of rhizospheric Pseudomonas and Bacillus as biocontrol tool for Xanthomonas campestris pv campestris. World Journal of Microbiology and Biotechnology 28:693-702.

Mougou, I.; Boughalleb-M'hamdi, N. 2018. Biocontrol of Pseudomonas syringae pv. syringae affecting citrus orchards in Tunisia by using indigenous Bacillus spp. and garlic extract.

Egyptian Journal of Biological Pest Control 28:60.

Peerj reviewing PDF | (2021:02:57892:2:0:NEW 10 Jul 2021) 
398 Nakajima, Y.; Kitpreechavanich, V.; Suzuki, K.; Kudo, T. 1999. Microbispora coralline sp.

399

400

401

402

403

404

405

406

407

408

409

410

411

412

413

414

415

416

417

418

419

420

421

422

423

424

425

426

427

428

429

430

431

432

433

434

435

436

nov., a new species of the genus Microbispora isolated from Thai soil. International journal of systematic and evolutionary microbiology 49:1761-1767.

Oh, D.C.; Poulsen, M.; Currie, C.R.; Clardy, J. 2009. Dentigerumycin: a bacterial mediator of an ant-fungus symbiosis. Nature Chemical Biology 5:391-393

Poulsen, M.; Oh, D.C.; Clardy, J; Currie, C.R. 2011. Chemical Analyses of wasp-associated Streptomyces bacteria reveal a prolific potential for natural products discovery. PLoS One 6(2):e16763.

Pridham TG, Lyons AJ. 1961. Streptomyces albus (Rossi Doria) Waskman et Henrici:

Taxonomic study of strains labeled Streptomyces albus. Journal of bacteriology 81:431-441. Promnuan, Y.; Kudo, T; Chantawannakul, P. 2009. Actinomycetes isolated from beehives in Thailand. World journal of microbiology and biotechnology 25:1685-1689.

Promnuan, Y.; Kudo, T.; Chantawannakul, P. 2011. Actinomadura apis sp. nov., isolated from a honey bee (Apis mellifera) hive, and the reclassification of Actinomadura cremea subsp.

rifamycini Gauze et al. 1987 as Actinomadura rifamycini (Gauze et al.1987) sp. nov., comb. nov. International journal of systematic and evolutionary microbiology 61:2271-2277.

Promnuan, Y.; Promsai, S.; Meelai, S. 2020. Antimicrobial activity of Streptomyces spp. isolated from Apis dorsata combs against some phytopathogenic bacteria. PeerJ 8:e10512.

Qian, F.; An, L.; He, X.; Han, Q.; Li, X. 2006. Antibacterial activity of xantho-oligosaccharide cleaved from xanthan against phytopathogenic Xanthomonas campestris pv. campestris. Process Biochemistry 41: 1582-1588.

Rangseekaew, P.; Pathom-aree, W. 2019. Cave actinobacteria as producers of bioactive metabolites. Frontiers in Microbiology 10: 387.

Rashad, F.M.; Fathy, H.M.; El-Zayat, A.S.; Elghonaimy, A.M. 2015. Isolation and characterization of multifunctional Streptomyces species with antimicrobial, nematicidal and phytohormone activities from marine environments in Egypt. Microbiology Research 175:34-47. Sabir, A.; El-Khalfi, B.; Errachidi, F.; Chemsi, I.; Serrano, A.; Soukri, A. 2017. Evaluation of the potential of some essential oils in biological control against phytopathogenic agent Pseudomonas syringae pv. tomato. Journal of plant pathology and microbiology 8(9):1000420.

Santisuk, J.; Promnuan, Y.; Khun-In, A.; Nimnoi, P; Ruanpanun, P. 2018. Efficiency of actinomycetes isolated from black dwarf honey bee (Apis andreniformis) in controlling root-knot nematode, Meloidogyne incognita causes root knot disease of chili in greenhouse; Journal of Agriculture 34(4): Available at: https://li01.tci-thaijo.org/index.php/joacmu/article/view/175422. (In Thai languages)

Satish, S.; Raveesha, K.A.; Jandrdhana, G.R. 2002. Antibacterial activity of plant extracts on phytopathogenic Xanthomonas campestris pathovars. Letters in Applied Microbiology 28:145147.

Scott, J.J.; Oh, D.C.; Yuceer, M.C.; Klepzig, K.D.; Clardy, J.; Currie, C.R. 2008. Bacterial protection of beetle-fungus mutualism. Science 322:63-63.

Peerj reviewing PDF | (2021:02:57892:2:0:NEW 10 Jul 2021) 
437 Shirling, E.B, Gottlieb, D. 1966. Methods for characterization of Streptomyces species.

438 International journal of systematic bacteriology 16:313-340.

439 Van Arnam, E.B.; Ruzzini, A.C.; Sit, C.S.; Horn, H.; Pinto-Tomas, A.A.; Currie, C.R.; Clardy, J.

440 2016. Selvamicin, an atypical antifungal polyene from two alternative genomic contexts.

441 Proceedings of the National Academy of Sciences of the United States of America 113:12940-

44212945.

443 Vicente, J.G.; Holub E.B. 2013. Xanthomonas campestris pv. campestris (cause of black rot of

444 crucifers) in the genomic era is still a worldwide threat to brassica crops. Molecular plant

445 pathology 14 (1):2-18.

446 Waksman SA. 1950. The actinomycetes: Their nature, occurrence, activities and importance.

447 Annales cryptogamici et phytopathologici 9: 1-230.

448 Wiegand, I.; Hilpert, K.; Hancock, R.E.W. 2008. Agar and broth dilution methods to determine

449 the minimal inhibitory concentration (MIC) of antimicrobial substances. Nature Protocols

450 3(2):163-175.

451 Wongsiri, S.; Lekprayoon, C.; Thapa, R.; Thirakupt, K.; Rinderer, T.E.; Sylvester, H.A.;

452 Oldroyd, B.P.; Booncham, U. 1996. Comparative biology of Apis andreniformis and Apis florea

453 in Thailand. Bee World 77(4):23-35.

454 Wu, J.; Pan, X.; Xu, S.; Duan, Y.; Luo, J.; Zhou, Z.; Wang, J; Zhou, M. 2019. The critical role of

455 cytochrome c maturation (CCM) system in the tolerance of Xanthomonas campestris pv.

456 campestris to phenazines. Pesticide Biochemistry and Physiology 156:63-71.

457 Wulff, E.G.; Mguni, C.M.; Mortensen, C.N.; Keswani, C.L; Hockenhull, J. 2002. Biological

458 control of black rot (Xanthomonas campestris pv. campestris) of brassicas with an antagonistic

459 strain of Bacillus subtilis in Zimbabwe. European Journal of Plant Pathology 10:317-25.

460 Yan, X.; Tao, J.; Luo, H.; Tan, L.; Rong, W.; Li H.; He, C. 2019. A type III effector XopL Xcc8004

461 is vital for Xanthomonas campestris pathovar campestris to regulate plant immunity. Research in

462 Microbiology 170(3):138-146.

463 Yoon, S. H.; Ha, S. M.; Kwon, S.; Lim, J.; Kim, Y.; Seo, H.; Chun, J. 2017. Introducing

464 EzBioCloud: A taxonomically united database of 16S rRNA and whole genome assemblies.

465 International Journal of Systematic and Evolutionary Microbiology 67:1613-1617. 


\section{Table $\mathbf{1}$ (on next page)}

Table 1. Number of actinomycetes isolated from $A$. andreniformis

Table 1. Number of actinomycetes isolated from $A$. andreniformis using four different media 
1 Table 1. Number of actinomycetes isolated from A. andreniformis using four different media

\begin{tabular}{|c|c|c|c|c|c|}
\hline \multirow[b]{2}{*}{ Sample source } & \multicolumn{4}{|c|}{ Isolation medium } & \multirow[b]{2}{*}{ Total (\%) } \\
\hline & ISP5* & SC* & $\mathrm{CZ}^{*}$ & NA* & \\
\hline Adults & 17 & 14 & 6 & 5 & $42(65.6 \%)$ \\
\hline Pupae & 1 & 0 & 0 & 0 & $1(1.6 \%)$ \\
\hline Pollen & 2 & 5 & 1 & 0 & $8(12.5 \%)$ \\
\hline Honey & 9 & 4 & 0 & 0 & $13(20.3 \%)$ \\
\hline Total (\%) & $29(45.3 \%)$ & $23(35.9 \%)$ & $7(10.9 \%)$ & $5(7.8 \%)$ & $64(100 \%)$ \\
\hline
\end{tabular}

2 *ISP5: Glycerol asparagine agar; SC: Starch casein nitrate agar; CZ: Czapek agar and NA: Nutrient agar

3 


\section{Table 2 (on next page)}

Table 2. Assignment of actinomycete isolates into four groups.

Table 2. Assignment of actinomycete isolates into four groups (I-IV) and 16S rDNA identification of the representative isolates. 
1 Table 2. Assignment of actinomycete isolates into four groups (I-IV) and 16S rDNA identification of the 2 representative isolates.

\begin{tabular}{|c|c|c|c|c|c|c|}
\hline Group & Morphological characteristics & Sources & $\begin{array}{c}\text { Occurrence } \\
\text { (\%) }\end{array}$ & $\begin{array}{l}\text { Representative } \\
\text { isolates }\end{array}$ & $\begin{array}{l}\text { Accession } \\
\text { No. }\end{array}$ & Genus \\
\hline I & $\begin{array}{l}\text { wrinkled colony with brown or } \\
\text { orange colour }\end{array}$ & $\begin{array}{l}\text { Adult } \\
\text { Adult }\end{array}$ & 7.8 & $\begin{array}{l}\text { AGA3-9 } \\
\text { AGA3-53 }\end{array}$ & $\begin{array}{l}\text { LC546088 } \\
\text { LC546089 }\end{array}$ & Micromonospora \\
\hline II & $\begin{array}{l}\text { convex and rigid colony with } \\
\text { cream colour }\end{array}$ & Adult & 3.1 & AGA3-58 & LC546090 & Actinomadura \\
\hline III & wrinkled colony with cream colour & Adult & 4.7 & ASC2-5 & LC546091 & Nonomuraea \\
\hline IV & $\begin{array}{l}\text { powdery colonies } \\
\text { aerial spore mass: white or grey }\end{array}$ & $\begin{array}{l}\text { Adult } \\
\text { Adult } \\
\text { Pollen }\end{array}$ & 84.4 & $\begin{array}{l}\text { ACZ2-27 } \\
\text { ASC3-2 } \\
\text { ASC5-7P }\end{array}$ & $\begin{array}{l}\text { LC500236 } \\
\text { LC506284 } \\
\text { LC506285 }\end{array}$ & Streptomyces \\
\hline
\end{tabular}

3 


\section{Figure 1}

Figure 1 Inhibitory effect of actinomycetes against growth of $X$. campestris pv. campestris.

Figure 1 Inhibitory effect of actinomycetes against growth of $X$. campestris pv. campestris:

(a) ACZ2-27 on ISP2 agar plate and (b) ASC3-2 and (c) ASC5-7P on GYE agar plates.

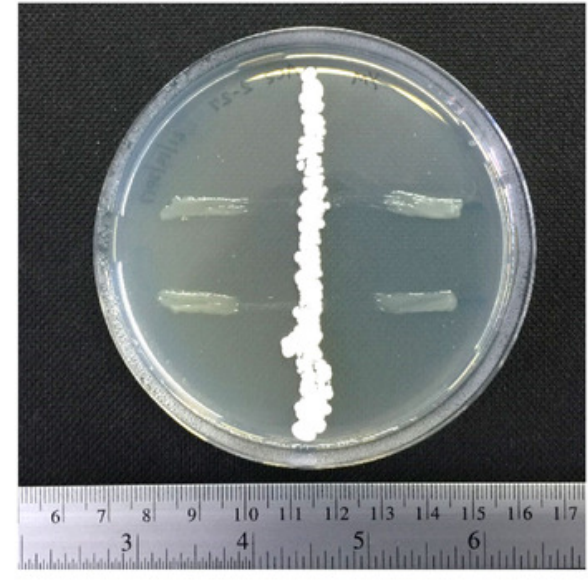

a

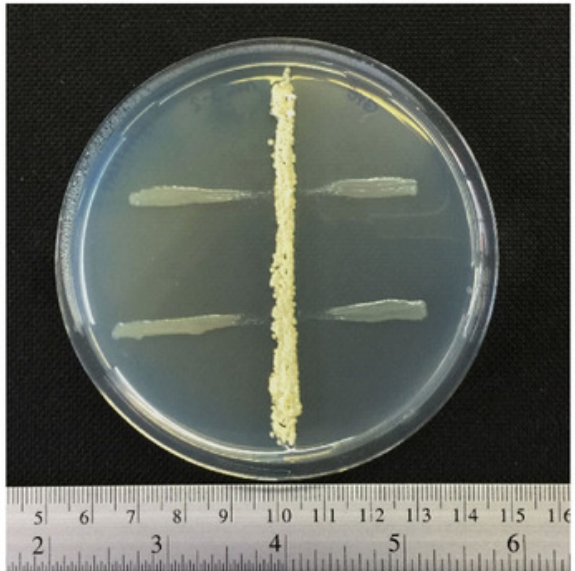

b

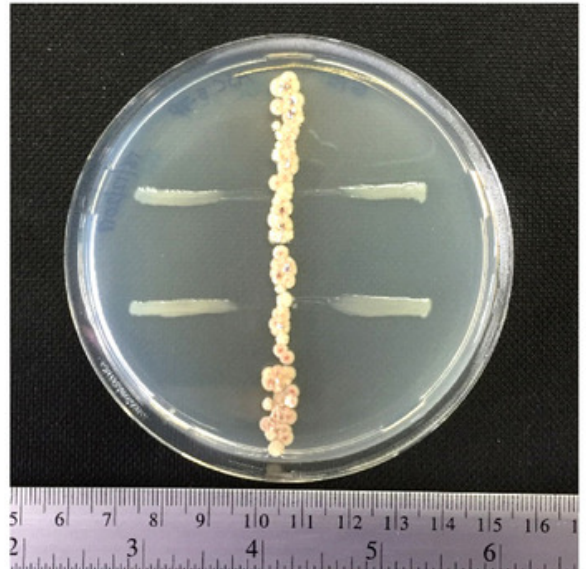

C 


\section{Figure 2}

Figure 2 The Maximum likelihood tree of antagonistic Streptomyces strains ACZ2-27, ASC3-2 and ASC5-7P

Figure 2 The Maximum likelihood tree based on 16S rRNA gene sequences $(1,296$ nucleotides) showing the phylogenetic position of antagonistic Streptomyces strains ACZ2-27, ASC3-2 and ASC5-7P relative to the type strains of other related Streptomyces species. Streptomyces thermocarboxydus DSM $44293^{\top}$ was used as an outgroup. The number at each node is the bootstrap support value (\%) based on 1,000 replicates (only values $>50 \%$ are shown). The bar shows 0.005 substitutions per nucleotide position. 


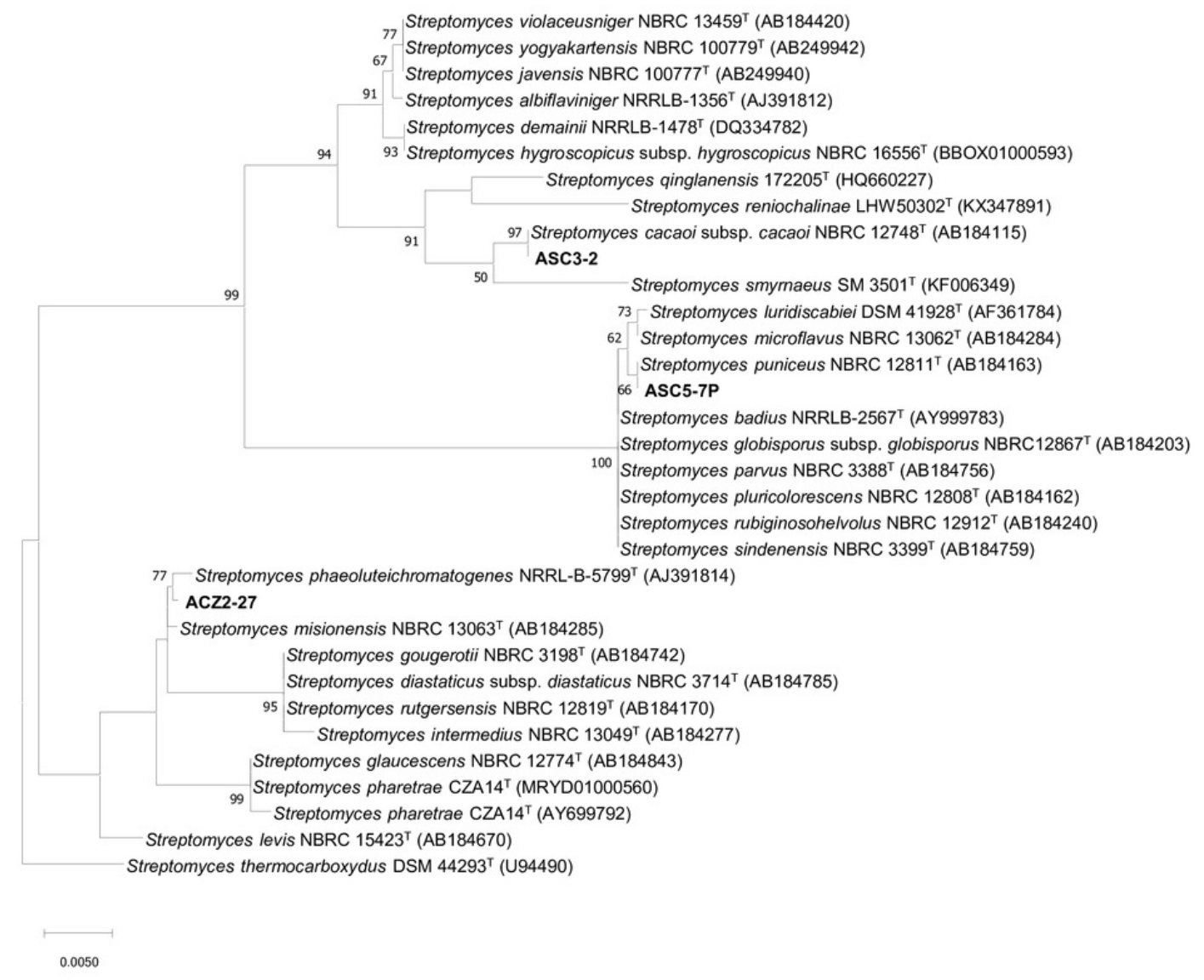




\section{Figure 3}

Figure 3 The Maximum likelihood tree of the representative strains of non-Streptomyces isolates

Figure 3 The Maximum likelihood tree based on 16S rRNA gene sequences $(1,297$ nucleotides) showing the phylogenetic position of the representative strains of nonStreptomyces isolates and their nearest neighbors. Streptomyces thermocarboxydus DSM $44293^{\top}$ was used as an outgroup. The number at each node is the bootstrap support value (\%) based on 1,000 replicates (only values $>50 \%$ are shown). The bar shows 0.01 substitutions per nucleotide position. 


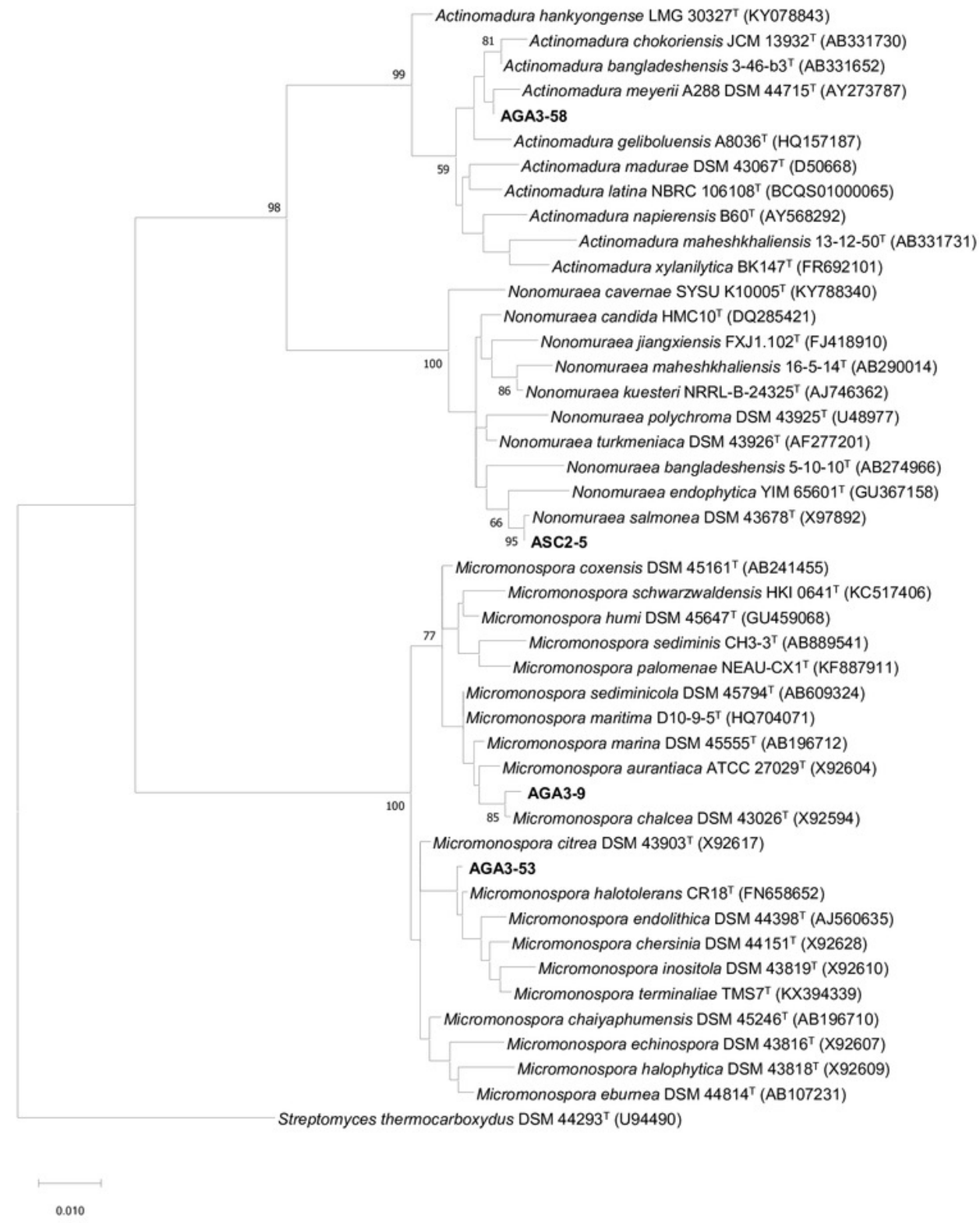

